Ryszard KOWALCZYK

Uniwersytet im. Adama Mickiewicza, Poznań

\title{
Ewolucja zawartości prasy lokalnej w Polsce w latach dziewięćdziesiątych XX wieku
}

\section{Analiza zawartości - uwarunkowania metodologiczno-teoretyczne}

Ja zawartość prasy lokalnej składają się przekazy ${ }^{1}$ (komunikaty), które 1 możemy traktować dwojako: 1) z punktu widzenia ich treści (konkretna wiadomość, informacja) oraz 2) formy (cechy formalno-gatunkowe wypowiedzi).

Badaniem zawartości prasy zajmuje się technika badawcza zwana analizą zawartości prasy, która służy do obiektywnego i ilościowego opisu przekazów prasowych i ich tematyki ${ }^{2}$. Żeby dobrze zrozumieć daną wypowiedź często jednak musimy wyjść poza jej bezpośrednią treść (czyli kontekst językowy) i zapoznać się z uwarunkowaniami społecznymi, jakie jej towarzyszyły (czyli kontekstem sytuacyjnym). Analiza zawartości prasy nie powinna więc opierać się tylko na bezpośrednim badaniu tekstów prasowych, lecz sięgać dalej i analizować również bezpośrednie otoczenie i szeroko pojęte środowisko prasy ${ }^{3}$.

Zaproponowany w naszych badaniach zawartości prasy lokalnej klucz kategoryzacyjny składa się z sześciu podstawowych grup (działów) te-

1 Przekazem jest zamknięty i uporządkowany według określonych reguł zbiór elementów wybranych z pewnego repertuaru znaków, przesyłany pomiędzy nadawcą i odbiorcą. Por. Encyklopedia wiedzy o prasie, pod red. J. Maślanki, Wrocław 1976, s. 202.

2 Por. Metody i techniki badawcze w prasoznawstwie, t I, pod red. M. Kafla, wyd. UW 1969, s. 32 i n.; P. Dubiel, Metody analizy zawartości prasy i jej praktyczne zastosowanie, w: Wstęp do prasoznawstwa, pod red. J. Mądrego, Katowice 1982, s. 170; W. Pisarek, Analiza zawartości prasy, Kraków 1983; I. S. Fiut, Analiza zawartości w świetle ewolucyjnej teorii poznania, ,Zeszyty Prasoznawcze” 1992, nr 1-2, s. 5-15; idem, Kierunki zmian $w$ analizie zawartości, „Zeszyty Prasoznawcze” 1995, nr 1, s. 147.

3 Por. I. S. Fiut, Analiza zawartości prasy w świetle ewolucyjnej teorii poznania, „Zeszyty Prasoznawcze” 1992, nr 1-2, s. 12 i n. 
matycznych obejmujących problematykę: 1) życia prywatnego (jednostka, rodzina, krag towarzyski, wartości, uczucia, przeżycia, opinie, oceny, postawy, zachowania itp.); 2) życia społecznego (grupa, zbiorowość, społeczność lokalna, środowisko społeczne, zakłady pracy, władza lokalna, partie polityczne itp.); 3) przyrody ożywionej i nieożywionej (flora i fauna oraz struktury geomorfologiczne); 4) rozrywki i humoru (krzyżówki, rebusy, zagadki, sentencje, przysłowia, satyra, konkursy, plebiscyty itp.); 5) reklamy i ogłoszeń oraz materiałów promocyjnych i komunikatów; 6) inne materiały (winieta, stopka redakcyjna, zapowiedzi redakcji, listy czytelników, spisy treści, przeglądy wydarzeń, program telewizyjny, informacje o nowych książkach, filmach, grach komputerowych, samochodach itp.). Wśród poszczególnych grup tematycznych można wyodrębnić w zależności od potrzeb badawczych dodatkowe kategorie i subkategorie.

Podczas przeprowadzania analizy zawartości prasy lokalnej, często dzielimy materiały na bezpośrednio lub pośrednio wiążące się z życiem danej społeczności. W ten sposób wyróżniamy lokalność pierwotną oraz wtórną przekazów. Analiza treści pisma lokalnego dostarcza także informacji o modelu zarządzania jego zawartością. Jeżeli w czasopiśmie dominują informacje dotyczące miejscowości stanowiącej centrum danej jednostki terytorialnej, na której jest rozpowszechniany określony tytuł prasowy, to możemy mówić o modelu centralistycznym. Drugi model jest pośredni, a jego cechąjest nadal przewaga materiałów z centrum przy stosunkowo dużym udziale materiałów $\mathrm{z}$ tak zwanego terenu. W trzecim modelu, który możemy nazwać zrównoważonym, istnieje względna równowaga materiałów poświęconych centrum i terenowi (peryferiom). Natomiast w czwartym, zdecentralizowanym, występuje przewaga materiałów $\mathrm{z}$ terenu, które dominują nad materiałami $\mathrm{z}$ centrum ${ }^{4}$.

Najczęściej wymienia się dwa rodzaje schematyzacji przekazów występujących w prasie: 1) schematyzację porządkującą jej ogólną zawartość (schematyzacja zewnętrzna), 2) schematyzację porządkującą konstrukcję przekazów (schematyzacja wewnętrzna).

W obrębie schematyzacji zewnętrznej znajduje się formuła redakcyjna, czyli profil tematyczny pisma wraz z preferowanymi formami prasowymi, oraz układ przekazów prasowych. Schematyzacja zewnętrzna nie

${ }^{4}$ Por. V. Holina, Przyczynek do charakterystyki miejskich, powiatowych i zaktadowych gazet lokalnych Stowacji, w: Z teorii i praktyki dziennikarstwa lokalnego, pod red. J. Mądrego, Katowice 1987, s. 49 i n. 
tylko porządkuje zawartość pisma, ale wyznacza także ramy przestrzenne dla poszczególnych materiałów oraz ich charakterystyczne formy.

Natomiast schematyzacja wewnętrzna odnosi się do budowy materiałów prasowych i wiąże się z pewnym reżimem oraz konwencją, wyznaczającymi łącznie cechy poszczególnych gatunków prasowych, ich schematy narracyjno-treściowe ${ }^{5}$.

W strukturze narracyjnej większości przekazów prasowych stosuje się najczęściej narrację linearną, charakteryzującą się wyraźnie określonym problemem (często jest to konflikt między osobami, instytucjami, wartościami, ideami lub ideologiami czy doktrynami). Jest on przybliżany czytelnikowi stopniowo - od ekspozycji tematu, jego rozwinięcia i kulminacji do zakończenia. Cechą narracji linearnej jest więc porządek chronologiczny prezentowanych zdarzeń, połączonych logicznymi związkami przyczynowo-skutkowymi. Narracja linearna jest podstawową zasadą konstrukcji tekstów dziennikarskich relacjonujących wydarzenia i zjawiska ${ }^{6}$.

Warto także zwrócić uwagę na wyodrębnienie się w prasie cyklu przekazów, czyli materiałów połączonych tematycznie i utrzymanych w podobnej konwencji. Może to być seria, składająca się zazwyczaj z zamkniętych epizodów, lub serial, rozwijający się tematycznie z odcinka na odcinek. Seria ma najczęściej konstrukcję linearną, przedstawiając jeden temat lub epizod. Natomiast serial opiera się głównie o konstrukcję paralelną, której cechą jest równoległość wątków lub ich przenikanie się. Ciągłe formy przekazów prasowych mają wiele zalet: są ważnym elementem stabilizującym podział zawartości pisma, w którym stały czytelnik dobrze się orientuje i jest często lojalnym odbiorcą danego cyklu tematycznego.

\section{Wypowiedzi dziennikarskie i niedziennikarskie}

Całość produkcji prasowej można podzielić na dwa rodzaje wypowiedzi: dziennikarskie i niedziennikarskie.

5 Por. M. Mrozowski, Media masowe. Władza, rozrywka i biznes, Warszawa 2001, s. 67-68.

6 Szerzej na temat prawdy, sofistyki i istoty przekazu zob. K. Jaspers, Von der Wahrheit. Philosophische Logik, Bd. 1, München 1947. 


\subsection{Wypowiedzi dziennikarskie}

W publikacjach dziennikarskich wyodrębnimy dwie grupy: informację i publicystykę. Na informację składają się wypowiedzi, których celem jest powiadomienie czytelnika o jakimś fakcie, dotyczącym bieżących lub przeszłych wydarzeń. Zatem informacje przenoszą głównie takie gatunki dziennikarskie, bardzo popularne w prasie lokalnej, jak między innymi: wzmianka, notatka, sprawozdanie, przegląd wydarzeń, sylwetka osoby, wywiad. Na tę kategorię wypowiedzi prasowych składają się najczęściej informacje wlasne redakcji. Informacyjne materiały pozaredakcyjne włączono do wypowiedzi niedziennikarskich. Ujęcie informacji w ten sposób oddaje, naszym zdaniem, w sposób bardziej precyzyjny jej udział w ogólnej zawartości miejscowych czasopism.

Wyróżnia się trzy podstawowe typy informacji: oficjalne, alternatywne, popularne ${ }^{7}$. W dziennikarstwie istnieje także utrwalony podział na informacje poważne, które odnoszą się do istotnych problemów i wydarzeń społecznych, politycznych, gospodarczych, kulturalnych i podlegają rzetelnej dziennikarskiej interpretacji i ocenie, oraz ciekawostki, dotyczące mniej istotnych zdarzeń i zjawisk z życia codziennego ludzi. Wiele pism lokalnych respektuje ten podział i wyraźnie oddziela informacje poważne od ciekawostek.

Jednak w niektórych gazetach i czasopismach komercyjnych występuje zjawisko przenikania się wymienionych wyżej kategorii typologicznych. Specyficzny takiemu opisowi rzeczywistości styl relacji prasowej charakteryzuje się czterema podstawowymi cechami: 1) fragmentacją, która polega na tym, że zdarzenia są traktowane jako odrębne fakty oderwane od szerszych uwarunkowań społecznych, politycznych czy ekonomicznych; 2) konkretyzacją, czyli przyjmowaniem faktów tu i teraz, bez dociekania przyczyn ich powstania, pochodzenia, celu itp.; 3) personalizacją, której konsekwencją jest uznanie działalności człowieka jako siły sprawczej wszelkich zdarzeń; ludźmi najczęściej więc nie kierują racje intelektualne, lecz żądze, emocje, nastroje oraz wybory moralne, polityczne, religijne i ideologiczne; 4) sensacjonalizmem, dla którego podstawowym środkiem relacji prasowej są elementy tragiczne, tragikomiczne, zaskakujące, szokujące czy bulwersujące.

7 Zob. J. Fiske, Popularity and the Politics of Information, w: Journalism and popular culture, red. P. Dahlgren, C. Sparks, London 1992. 
Do publicystyki zaliczono materiały, dla których jakieś zdarzenie było jedynie zaczynem, środkiem czy osią, wokół której organizowano wypowiedź dziennikarską ${ }^{8}$. Na takiej podstawie autor publikacji kształtował sobie własny punkt widzenia opisywanej rzeczywistości społecznej, gospodarczej, politycznej. Materiał publicystyczny wcale nie musiał być krytyczny wobec przedstawianych wydarzeń. Utwór aprobujący mógł spełniać wszelkie wymogi stawiane przed publicystyką. Jego istotą pozostawał odautorski, indywidualny stosunek (komentarz) do problematyki stanowiącej treść publikacji. Do podstawowych publicystycznych gatunków dziennikarskich, wykorzystywanych w praktyce prasy lokalnej, zalicza się przede wszystkim komentarz i artykuł, rzadziej reportaż i felieton.

Wypowiedzi dziennikarskie zajmowały w latach 1989-1992 około 66\% ogólnej powierzchni prasy lokalnej. Ich udział ulegał jednak w tym czasie systematycznemu zmniejszaniu (dynamika wyniosła w tym okresie 75).

\subsection{Wypowiedzi niedziennikarskie}

W ramach wypowiedzi niedziennikarskich można wyodrębnić przynajmniej osiem kategorii tematycznych, takich jak: 1) literatura (nowele, opowiadania, powieści itp.), 2) satyra i karykatura, 3) poezja, 4) listy czytelników, 5) ogłoszenia, reklama, promocja, 6) komunikaty, 7) rozrywka i humor, 8) inne (na przykład program telewizyjny, fotografie i rysunki samoistne, konkursy i plebiscyty). Zajmowały one średnio około 34\% powierzchni czasopisma lokalnego, ukazującego się w latach 1989-1992, systematycznie zwiększając swój udział (dynamika wyniosła w tym okresie 191).

Materiały niedziennikarskie, stanowiąc drugi ważny segment zawartości prasy lokalnej, odgrywały w niej rolę uzupełniająca, podnosząc atrakcyjność czasopisma. Można nawet powiedzieć, że prasa jako taka, a zwłaszcza komercyjna, nie istnieje bez wypowiedzi niedziennikarskich, w tym głównie reklamy i ogłoszeń (mamy tutaj na myśli przede wszystkim aspekt ekonomiczny prasy, warunkujący jej istnienie na rynku'). Po-

8 Por. M. Szulczewski, Publicystyka. Problemy teorii i praktyki, Warszawa 1976, s. $48 \mathrm{i} \mathrm{n}$.

9 Por. W. Pisarek, Prasa - nasz chleb powszedni, Ossolineum 1978, s. 222-237. Cyt.: „wydawnictwo oferując czytelnikowi gazetę poniżej kosztów jej wyprodukowania, wychodzi na swoje tylko dzięki temu, że tę samą powierzchnię papieru sprzedaje 
nad 4/5 ich powierzchni przypadało na reklamę i ogłoszenia, inne materiały (program telewizyjny, fotografie i rysunki stanowiące samoistne wypowiedzi, konkursy dla czytelników) oraz rozrywkę i humor. W odróżnieniu od materiałów dziennikarskich, wypowiedzi niedziennikarskie systematycznie z roku na rok zwiększały swój udział. Pod koniec lat dziewięćdziesiątych zajmowały prawie $3 / 5$ powierzchni miejscowych periodyków. Dominujący udział w materiałach niedziennikarskich posiadały takie kategorie tematyczne, w kolejności, jak: reklama i ogłoszenia, materiały inne (w tym program telewizyjny, konkursy, fotografie i rysunki samoistne), rozrywka i humor, listy czytelników.

\section{Informacyjno-publicystyczny charakter prasy lokalnej}

Informacyjny charakter lokalnych wydawnictw prasowych potwierdzają wyniki badań. Oznajmujące wypowiedzi dziennikarskie zajmowały w latach 1989-1992 prawie 57\% objętości miejscowych periodyków. Publicystyce poświęcano niewiele miejsca - niespełna 1/10 powierzchni.

Publicystyka, choć poświęcano jej niewiele miejsca, utrzymywała się w latach dziewięćdziesiątych XX wieku na względnie stałym poziomie. Dynamiczny wzrost udziału tej kategorii (o ponad 9\%) odnotowano w 1990 roku. Udział publicystyki w ogólnej objętości miejscowej prasy zwiększał się w ważnych momentach historycznych (tak było na przełomie lat 1990/1991 w czasie wprowadzania w Polsce fundamentalnych reform politycznych i gospodarczych, które przecież wywoływały w społeczeństwie określone napięcia i spory) oraz w okresach, którym towarzyszyły konflikty społeczne, afery gospodarcze, kampanie społeczno-polityczne i przedwyborcze.

W lokalnych wydawnictwach prasowych przeważa informacja nad publicystyką, a część niedziennikarska zajmuje znaczące miejsce w ich ogólnej objętości. Pismo lokalne jest więc jednocześnie wydawnictwem informacyjno-publicystycznym i rozrywkowo-reklamowym, w którym publikacje niedziennikarskie mają ugruntowaną, ważną pozycję. Do takich samych konkluzji doszli także inni badacze zajmujący się tą problematyką ${ }^{10}$.

dwukrotnie. Po raz pierwszy za tę samą powierzchnię płaci reklamująca się instytucja, po raz drugi - czytelnik" (ibidem, s. 223).

10 Por. M. Gierula, B. Grzonka, Prasa lokalna w latach 1989-1991, „Zeszyty Prasoznawcze” 1992, nr 1-2, s. 126-127. Cyt.: „Zdecydowana większość omawianych 
Przeciętne czasopismo lokalne skupia się na przekazywaniu czytelnikom podstawowych informacji o konkretnych zdarzeniach, towarzyszących im zjawiskach i procesach oraz stara się pełnić wobec nich funkcję rozrywkowo-reklamową. Poprzez stosunkowo niewielki udział publicystyki wydawnictwa miejscowe nie dokonują oceny wielu aspektów wydarzeń oraz nie wartościują przedstawianych faktów. W prasie lokalnej przeważa zatem funkcja powiadamiania (referowania) nad funkcją oddziaływania (ksztaltowania opinii). Chociaż sama informacja jako taka może wywoływać, i często wywołuje, wśród czytelników określone emocje i predyspozycje, które mogą przecież być uproszczone, stronnicze, nie odpowiadając rzeczywistości. Zatem pozbawiona komentarza prosta informacja, nie zawsze bierze pod uwagę ograniczone zdolności interpretacyjne odbiorcy. Dlatego w rezultacie może prowadzić czytelnika na manowce.

Coraz częściej pojawia się w praktyce dziennikarstwa lokalnego postawa neutralna. Jej rezultatem jest akceptacja tego, co powinno być napiętnowane. Dążenie do prawdy, jaka by ona nie była, zostaje zastąpione rytualnym i protekcjonalnym oraz paternalistycznym i konformistycznym stosunkiem do otoczenia. Wygoda dziennikarzy i wydawców, a także wymogi dyktowane przez warunki konkurencyjnego i skomercjalizowanego rynku prasowo-wydawniczego i reklamowego determinują postawę dziennikarzy i wydawców, którzy, unikając niepotrzebnego rozgłosu społecznego i krytyki, mają na uwadze przede wszystkim własny interes.

\section{Czynniki wpływu na tematykę piśmiennictwa lokalnego}

Treść prasy lokalnej jest nierozerwalnie związana z wszelkiego rodzaju przejawami życia społeczno-politycznego, kulturalnego, obyczajowego,

pism od samego początku przybrała charakter informacyjno-publicystyczny. Operując głównie krótkimi formami informacyjnymi - niekiedy z elementami oceny zjawisk, zdarzeń, faktów" (ibidem, s. 127). Zob. także Wł. Chorązki, Obraz niezależnej prasy lokalnej w Polsce w I połowie 1994 r., Kraków 1994. Autor tak pisze: „Z analizy 123 ankiet i egzemplarzy konkretnych tytułów prasowych wynika, iż 97\% gazet uczestniczących w konkursie spełnia [...] funkcję informacyjną” (ibidem, s. 57). Por. D. B. Rudnicki, Prasa lokalna województwa bydgoskiego (1989-1991), w: Transformacja prasy polskiej (1989-1992), Warszawa 1992, s. 192; S. Michalczyk, Gazeta lokalna jako element komunikacji społecznej (na przykładzie Rodni), w: Społeczności lokalne i rozwój demokracji lokalnej, pod red. M. Barańskiego, Katowice 1993, s. 62-63. 
gospodarczego, mieszkańców żyjących na obszarze jej rozpowszechniania. Jej zawartość odzwierciedla życie społeczności, rejestruje ważne wydarzenia, opisuje zjawiska i procesy oraz pilnie śledzi przemiany zachodzące w środowisku, dostarczając czytelnikom wielu ważnych informacji, wiedzy, rozrywki i reklamy.

W ostateczności struktura tematyczna mediów lokalnych jest pochodną potrzeb i zainteresowań odbiorców. Dlatego musi być zgodna nie tylko $\mathrm{z}$ ich ogólnymi preferencjami treściowymi, ale także na tyle zróżnicowana tematycznie, żeby odpowiadała heterogenicznym zainteresowaniom czytelników. Badania prasy lokalnej umożliwiają jej podział (klasyfikację) ze względu na profil tematyczny i zainteresowania. Wynikiem analizy jest również określenie preferencji nadawców lokalnych i założeń ich polityki informacyjnej oraz wskazanie czynników wpływu na zakres zainteresowań prasy.

$\mathrm{Na}$ strukturę zawartości określonego wydawnictwa wpływa:

1) wydawca, który określa profil tematyczny pisma odzwierciedlający jego preferencje, zainteresowania, system wartości, poglądy społeczno-polityczne, interesy i potrzeby;

2) środowisko społeczne, w którym jest kolportowane czasopismo, w szczególności: a) struktura geograficzno-przestrzenna, b) struktura społeczno-zawodowa, c) predyspozycje psychofizyczne mieszkańców (na przykład: odpowiedzialność, zaradność, aktywność, cierpliwość, dzielność, męstwo, odwaga, ambicja, odporność na stres itp.), d) kultura, e) struktura ekonomiczno-gospodarcza;

3) polityka redakcyjna, która może preferować pewne tematy i ograniczać udział innych zagadnień w zawartości pisma, na co ma znaczący wpływ między innymi przygotowanie zawodowe dziennikarzy, ich profesjonalizm i interesy;

4) potrzeby, oczekiwania i zainteresowania odbiorców i reklamodawców.

Wpływ tych czynników na strukturę tematyczną pisma jest niejednakowy. Ważną rolę odgrywają najczęściej określona polityka wydawniczo-redakcyjna oraz oczekiwania i potrzeby odbiorców i reklamodawców.

Polityka redakcyjno-wydawnicza ujmuje w sobie wpływy dwu głównych czynników: wydawcy oraz członków redakcji i dziennikarzy. Oddziaływanie wydawcy na strukturę tematyczną określonego pisma może być stałe (ciagły i systematyczny nadzór nad zawartością czasopisma) lub doraźne (okresowe). Wydawca, zwłaszcza komercyjny, może oddać kierowanie tytułem prasowym w ręce redakcji lub rady redakcyjnej, 
która mając na uwadze głównie interesy ekonomiczne wydawnictwa stara się realizować taką politykę w dziedzinie zawartości pisma, żeby osiagnąć zamierzone i oczekiwane przez wydawcę cele handlowe. Sprzyja temu odpowiadanie na konkretne potrzeby i zainteresowania odbiorców, których preferencje w dużym stopniu wpływają na strukturę zawartości pisma. Jest ona również pochodną określonych interesów nadawcy komercyjnego, którego dochody w ostateczności determinuje liczba czytelników czasopisma, wyznaczając $\mathrm{w}$ ten sposób również konkretną cenę reklamy i ogłoszenia.

\section{Pluralizm treści}

Prasa lokalna jest tematycznie pluralistyczna. Stara się odzwierciedlać życie miejscowych społeczności we wszystkich jego płaszczyznach i dokonywać publicystycznej refleksji nad tym, co się dzieje w środowisku. Nie tylko odzwierciedla rzeczywistość, lecz niekiedy także ją kreuje. Czasami dostarcza odbiorcom powierzchowne, sfragmentaryzowane, spolaryzowane, niereprezentatywne, zsubiektywizowane jej odbicie. Dane wydarzenie zostaje wybrane spośród wielu innych. Selekcja następuje z określonego przez nadawcę powodu i jest skorelowana nie tylko $\mathrm{z}$ bieżącymi potrzebami i zainteresowaniami czytelników, ale $\mathrm{w}$ dużym stopniu $\mathbf{z}$ interesem nadawcy. Obrazy wydarzeń, zjawisk, procesów, tendencji, ukształtowanych w świadomości odbiorców przez media, zaczynają niekiedy zastępować opisywaną rzeczywistość i stają się rzeczywistością wirtualną, którą akceptuje czytelnik. To jest jedna z przyczyn powodujących zubożenie treści relacji międzyludzkich, które opierają się często nie na bezpośrednich kontaktach i obserwacji otoczenia, lecz na informacjach dostarczanych przez media. W konsekwencji możemy mówić o micie rzeczywistości (jej zindywidualizowanym i nieobiektywnym wyobrażeniu), której podstawowym kreatorem są najczęściej media, w tym także miejscowa prasa ${ }^{11}$.

Zawartość prasy lokalnej ma nie tylko wymiar treściowy i odpowiadający mu zakres tematyczny. Ale również wymiar przestrzenny (geograficzny), gdyż zakotwicza daną problematykę w konkretnym środowisku. W taki sposób możemy wskazać obszary i problemy często reprezentowane

11 Zob. noworoczne wydanie tygodnika, „Newsweek” 2002, nr 1, styczeń. 
w mediach oraz miejsca i zagadnienia, o których relacje na łamach czasopisma są rzadkie lub w ogóle ich nie ma. Pomijając w swoich jednostronnych relacjach pewne osoby, społeczności, grupy, organizacje, opinie, sądy, oceny, idee, prasa nie daje odbiorcom pełnego obrazu poglądów, postaw, zachowań oraz przemian i tendencji, jakie zachodzą w danym środowisku. W ten sposób fragmentaryzując, personalizując oraz polaryzując rzeczywistość, prowadzi do jej wypaczenia i zniekształcenia. W rezultacie nie jest reprezentatywna.

Wiele tytułów miejscowych zajmuje się podobną tematyką, zachowując jednak prawo do jakościowej odmienności relacji, komentarzy, opinii, ocen czy stopnia krytycyzmu. Na taką postawę wydawców wpływa szereg czynników, wśród których można wymienić między innymi: 1) status formalnoprawny wydawnictwa, 2) poglądy polityczne nadawcy oraz 3) politykę informacyjną wydawnictwa.

\section{Podział ogólnej zawartość prasy lokalnej}

Na zawartość ogólnoinformacyjnych tytułów lokalnych składały się między innymi takie zagadnienia, jak ${ }^{12}$ :

1) problematyka polityczna, która ogniskuje się wokół szeroko ujmowanej tematyki funkcjonowania władz lokalnych, działalności partii politycznych i ich liderów oraz elit miejscowego środowiska ${ }^{13}$, a także dotyczy wszelkich przejawów, form i sposobów udziału mieszkańców i ich organizacji we władzy lokalnej i wywierania na nią wpływu oraz przejawiania się demokracji, jej wartości, zasad i norm ${ }^{14}$;

12 Por. S. Michalczyk, Media lokalne w systemie komunikowania. Współczesne tendencje $i$ uwarunkowania rozwojowe, Katowice 2000, s. 124-126.

13 Jak podaje Stanisław Michalczyk, posiłkując się wynikami badań niemieckich (N. Jonscher, Lokale Publizistik. Theorie und Praxis der örtlichen Berichterstattung. Ein Lehrbuch, Opladen 1995, s. 465), w lokalnych dziennikach najczęściej występującymi osobami byli: przedstawiciele władz lokalnych, artyści, działacze partyjni, reprezentanci grup interesów, sportowcy, kler, ludzie z marginesu społecznego, przedsiębiorcy i pojedyncze osoby fizyczne (niezrzeszeni). Podaję za S. Michalczyk, Media lokalne $w$ systemie komunikowania, op. cit., przypis 26 na s. 125.

14 Więcej na temat funkcjonowania lokalnego życia politycznego w Polsce można się dowiedzieć z publikacji Polityczne życie lokalne, pod red. J. Wodza, Katowice 1994. 
2) problematyka organizacji pozarządowych, która odzwierciedla przejawy życia organizacyjnego, osiagnięcia, inicjatywy, problemy stowarzyszeń i fundacji oraz pokazuje działalność ich zarządów, kierowników i wolontariuszy;

3) problematyka gospodarcza, na którą składają się informacji o miejscowej przedsiębiorczości, zakładach pracy, zatrudnieniu oraz funkcjonowaniu rynku lokalnych usług materialnych m.in.: handlu, gastronomii, komunikacji, telekomunikacji, gospodarki komunalnej, budownictwa mieszkaniowego;

4) usługi niematerialne, zagadnienia te ilustrują publiczną i instytucjonalną działalność szkoleniowo-oświatową, kulturalną, rekreacyjna, naukową, prezentując również osiągnięcia miejscowych zespołów artystycznych, szkół, domów kultury, bibliotek, sylwetki wybitnych twórców i działaczy kultury oraz nauki i edukacji;

5) problematyka socjalna i społeczno-obyczajowa, która pokazuje ekonomiczne i społeczno-socjalne problemy środowiska, przykłady różnych patologii oraz działalność organów ścigania i wymiaru sprawiedliwości, a także odzwierciedla przejawy życia społecznego i ważne wydarzenia;

6) problematyka życia religijnego, na którą składają się informacje dotyczące działalności kościołów i związków wyznaniowych oraz przedstawiające formy i przejawy uczestnictwa ludzi w uroczystościach religijnych i wspólnocie wyznawców;

7) problematyka sportu lokalnego, której przedmiotem zainteresowania jest działalność sportowa oraz turnieje, mistrzostwa, jakie odbywają się w różnych dyscyplinach sportu, pokazywanie sylwetek zwycięzców, trenerów itp.

\section{Przegląd tematyki prasy lokalnej}

Przyjrzyjmy się zatem tematyce prasy lokalnej. W pierwszej kolejności zajmiemy się analizą jej struktury tematycznej. Jak już wspominano tworzy ją sześć charakterystycznych grup tematycznych: 1) życie prywatne, 2) życie społeczne, 3) przyroda ożywiona i nieożywiona, 4) rozrywka i humor, 5) reklama, ogłoszenia, materiały promocyjne i komunikaty, 6) inne materiały.

Największy odsetek zajmowała problematyka życia społecznego, której udział systematycznie się zmniejszał. Przeciętne pismo lokalne wydawane w 1989 roku oddawało swoje łamy w większości ważnym 
zagadnieniom społecznym, wśród których dominowała tematyka kulturalno-historyczna i ciekawostki, spychające na dalsze miejsca życie prywatne jednostki, reklamę i ogłoszenia. W latach następnych sytuacja w tej dziedzinie zmieniała się na korzyść materiałów reklamowo-ogłoszeniowych, które wypierały zagadnienia społeczne. Pod koniec lat dziewięćdziesiątych już tylko $2 / 5$ objętości prasy lokalnej zajmowała problematyka społeczna, gdzie najwięcej miejsca poświęcano funkcjonowaniu samorządu terytorialnego, kulturze i edukacji oraz informacjom sportowym i rekreacji. Pojawiało się za to coraz więcej materiałów reklamowych i ogłoszeń. Zwiększał się udział informacji użytkowych, szczególnie takich, jak programy stacji telewizyjnych i radiowych czy przeglądy nowości na rynku wydawnictw książkowych, muzycznych, gier komputerowych. W latach następnych programy telewizyjne i radiowe drukowane w prasie lokalnej, zastępowały kolorowe wkładki radiowo-telewizyjne.

O ile udział problematyki społecznej w objętości prasy miejscowej w badanych latach systematycznie się zmniejszał, o tyle problemy życia prywatnego, a zwłaszcza informacje o przestępczości, wypadkach losowych, zainteresowaniach indywidualnych, także sylwetki wybitnych postaci miejscowego środowiska i informacje o ich życiu prywatnym, zajmowały coraz więcej miejsca.

Wraz z rozwojem rynku konsumenta i kształtowaniem się wolnorynkowych form przedsiębiorczości pojawiło się także zapotrzebowanie na efektywne środki promocji i reklamy. Potrzeby te zaspokajały w mniejszym lub większym stopniu także media o lokalnym charakterze, stając się dla miejscowych przedsiębiorców atrakcyjnym środkiem reklamy i promocji ich wyrobów i usług - o czym świadczy systematyczny wzrost udziału tej grupy tematycznej w objętości pism lokalnych przez cały badany okres. Pod koniec lat dziewięćdziesiątych reklama, ogłoszenia i materiały promocyjne zajmowały prawie tyle samo miejsca, co zagadnienia społeczne. Podobny wzrost zanotowały: program telewizyjny, sport, ogłoszenia oraz rozrywka i humor. Obrazują one generalną tendencję w rozwoju prasy lokalnej, która polega na odchodzeniu od tematyki społecznej na rzecz informacji o problemach konkretnych ludzi, sporach i konfliktach jednostek, grup, społeczności, władz lokalnych oraz informacji bardziej przydatnych na co dzień i praktycznych (na przykład rozbudowane działy różnorakiego poradnictwa). Przeciętny tytuł lokalny to wydawnictwo o przewadze problematyki społecznej nad zagadnieniami życia prywatnego, w którym dużą rolę odgrywały reklama i ogłoszenia. Osią zainteresowania redakcji stały się poszczegól- 
ne środowiska i zbiorowości lokalne oraz gospodarka, kultura, sport, wypoczynek, rekreacja i samorząd terytorialny.

Przedstawione dane potwierdzają znaną $w$ prasoznawstwie tezę o wypieraniu z popularnego rynku poważnych tematów przez ciekawą, lecz pospolitą problematykę. Przeważają zagadnienia o charakterze sensacyjnym, intrygującym, niesamowitym oraz materiały rozrywkowe, sportowe i o walorach użytkowych, takie jak przeglądy nowości na rynku usług i towarów oraz różnego rodzaju poradnictwo. Na rynku informacyjnym królują wiadomości - jeżeli można tak powiedzieć - łatwe, lekkie i przyjemne. Na takie materiały prasowe istnieje zapotrzebowanie społeczne. Stąd też nie ma się co dziwić, że redaktorzy, dziennikarze i wydawcy periodyków lokalnych starają się wyjść mu naprzeciw. W rezultacie bardziej wartościowe materiały dziennikarskie są wypierane przez gorsze, lecz akceptowane przez większość odbiorców. Konsekwencją takiej sytuacji jest nieuchronne obniżanie się poziomu kultury w ogóle, co potwierdza także szerząca się, niestety, wulgaryzacja słownictwa prasowego, która wpływa negatywnie na kształt relacji społecznych.

\section{Zawartość tygodników lokalnych}

Analizując strukturę zawartości tematycznej tygodników lokalnych, stwierdzimy, że najwięcej miejsca w ich ogólnej objętości zajmowała problematyka społeczna, chociaż jej udział systematycznie się zmniejszał. Podobna tendencja występuje we wszystkich rodzajach pism lokalnych. Miejsce zwolnione przez zagadnienia społeczne, wypełniają inne materiały, przede wszystkim reklama, ogłoszenia, życie prywatne oraz sport i rozrywka. Zmniejszał się również udział problematyki ekonomiczno-gospodarczej, kultury i sztuki oraz polityki. Natomiast zwiększał się udział materiałów bardziej interesujących przeciętnego czytelnika: dotyczących przestępczości i funkcjonowania służb mundurowych (policji, straży miejskiej, straży pożarnej), samorządu terytorialnego, wydarzeń sportowych. Zagadnienia społeczne i reklama zajmowały prawie po 1/3 objętości tygodników.

Materiały reklamowe i ogłoszenia zajmowały w badanym okresie poczesne miejsce w lokalnej prasie tygodniowej. Ich udział systematycznie się zwiększał, wykazując największą dynamikę. W jej zawartości ważne miejsce zajmują: ciekawostki, przeglądy wydarzeń, kalendaria oraz program telewizyjny i radiowy. 
W minionym okresie zwiększała się również objętość materiałów dostarczających odbiorcom relaksu, zabawy i wytchnienia. Pojawiało się coraz więcej konkursów dla czytelników, krzyżówek, rebusów i innych rozrywek umysłowych. W pismach o większej częstotliwości więcej miejsca zajmuje problematyka „zwykłego człowieka”, ogłoszenia i reklama oraz sport i rozrywka. Jest to zrozumiałe, gdyż w wydawnictwach ukazujących się rzadziej (raz na miesiąc lub dwa miesiące, czy raz w kwartale) nie można zachować oczekiwanej przez czytelników aktualności. Podobnie jest z reklamą i ogłoszeniami, które przy miesięcznym cyklu wydawniczym tracą aktualność i nie mogą się cieszyć takim zainteresowaniem ze strony ogłoszeniodawców, jak dzienniki i tygodniki czy dwutygodniki.

W tygodnikach w dziale życie prywatne przodowały wiadomości o różnego rodzaju przestępstwach kryminalnych i innych wypadkach oraz wykroczeniach (kradzieże, napady, rozboje, włamania, zabójstwa, wypadki drogowe itp.). W obrębie problematyki życia społecznego na czele znalazły się informacje kulturalno-edukacyjne, którym nieznacznie uległy wiadomości sportowe i turystyczno-rekreacyjne. Tematyka samorządu terytorialnego była na trzecim miejscu. Tak stabilny rozkład tej tematyki utrzymywał się w tygodnikach już od 1991 roku. Wśród wymienionych kategorii tematycznych, podobnie jak w roku poprzednim, na czele znajdowała się reklama.

\section{Zawartość miesięczników lokalnych}

W miesięcznikach, podobnie jak w tygodnikach, najwięcej miejsca poświęcano problematyce społecznej, której udział systematycznie się zmniejszał w badanym okresie. Jest to tendencja utrzymująca się we wszystkich periodykach lokalnych. Tygodniki jednak ze swej natury są nastawione na przekazywanie informacji o bieżących wydarzeniach. Więcej tam materiałów sensacyjnych, dotyczących zdarzeń losowych, omawiających funkcjonowanie władz samorządowych oraz przedstawiających różnego rodzaju opinie, poglądy i sądy na tematy aktualne. Dużo miejsca zajmują reklama i ogłoszenia oraz wiadomości sportowe. W miesięcznikach jest natomiast mniej materiałów sensacyjnych i dotyczących aktualnych wydarzeń. Więcej za to artykułów problemowych poruszających zagadnienia ponadczasowe, informacji z dziedziny kultury i sztuki oraz historii lokalnej i regionalnej. 
Udział reklamy i ogłoszeń w ogólnej objętości miesięczników zwiększał się. Najwięcej miejsca w tej grupie zajmuje reklama, natomiast zdecydowanie mniej jest ogłoszeń drobnych. Dla ogłoszeniodawców miesięczniki nie są atrakcyjnym miejscem zamieszczania anonsów, stąd orientują się przede wszystkim na tygodniki względnie dwutygodniki, zapewniające większą aktualność.

Życie prywatne zajmowało w miesięcznikach niewiele miejsca. Do tej tematyki można zaliczyć porady różnego rodzaju oraz materiały poruszające problemy konkretnych ludzi, omawiające warunki ich życia, odnoszące się do świata wartości, wyobrażeń, idei i religii. Znajduje się tu miejsce na głębszą refleksję nad życiem społecznym i duchowym człowieka, ekonomią oraz sprawami, dla których nie ma najczęściej miejsca w tygodnikach, koncentrujących się głównie na bieżących wydarzeniach.

W miesięcznikach najwięcej miejsca zajmuje problematyka społeczna - prawie $2 / 3$ objętości, natomiast reklama i ogłoszenia niespełna $1 / 6$ objętości.

\section{Zawartość prasy prywatnej i samorządów terytorialnych}

Obserwując przeobrażenia tematyki prasy lokalnej można zauważyć bardzo wyraźne tendencje i procesy. Do głównych wskaźników zmian należy niewątpliwie zmniejszenie się objętości tekstów poświęconych ogólnie pojętemu życiu społecznemu i innej problematyce oraz systematyczny wzrost udziału materiałów dotyczących życia prywatnego oraz reklamy i ogłoszeń. Zobaczmy jakie w tym zakresie przeobrażenia dotknęły czasopism prywatnych i samorządów terytorialnych.

Pierwsze legalne prywatne inicjatywy prasowo-wydawnicze na szczeblu lokalnym pojawiły się dopiero w 1990 roku. W tych wydawnictwach stosunkowo dużo miejsca zajmowały przeglądy wydarzeń, ciekawostki oraz ogłoszenia i reklama. Czasopisma samorządów terytorialnych poświęcały tej problematyce mniej uwagi.

Na tym przykładzie widać, jak bardzo pisma prywatne nastawione są na sukces komercyjny, który zapewnia im przetrwanie na lokalnym rynku prasowo-wydawniczym. Sukces ten gwarantują nie tylko dochody ze sprzedaży czasopisma, ale nade wszystko wpływy z reklamy i ogłoszeń stąd też znaczny udział tych materiałów w ogólnej objętości pism prywatnych. W wydawnictwach samorządów terytorialnych kwestie dochodowości pisma są problemem drugoplanowym. Liczą się nie wpływy 
finansowe z działalności prasowo-wydawniczej, lecz ogólne znaczenie i rola pisma w środowisku. Gazeta jest dla władz lokalnych swego rodzaju spirytus movens i środkiem promocji ich działalności oraz budowania w społeczeństwie zaufania do miejscowej władzy i jej liderów.

W czasopismach prywatnych wśród poszczególnych kategorii tematycznych działu życie społeczne przodowały zagadnienia kulturalno-edukacyjne. Ustępowała im między innymi tematyka samorządu terytorialnego, sport, turystyka, wypoczynek i rekreacja oraz humor i rozrywka. Dużą część objętości zajmowały reklama, program telewizyjny i ogłoszenia. Rozkład problematyki społecznej jest podobny w obu kategoriach wydawnictw. Przodowały informacje kulturalno-edukacyjne, dalej znajdowały się zagadnienia poświęcone funkcjonowaniu samorządów terytorialnych.

Taki układ struktury tematycznej w prasie samorządów terytorialnych jest zrozumiały. Jest ona bowiem traktowana przez większość wydawców jako względnie efektywny środek komunikowania się władz samorządowych z mieszkańcami. Stąd też odpowiednio duża część objętości tych tytułów jest zajęta przez problematykę samorządu terytorialnego jako instytucji publicznej i ośrodka władzy lokalnej. Z drugiej zaś strony ich redakcje, mając zapewnione środki finansowe na kontynuowanie wydawnictwa, nie muszą aż tak bardzo zabiegać o czytelnika oraz o dodatkowe dochody finansowe, pochodzące głównie z reklamy i ogłoszeń. Samorządy terytorialne - jako wydawcy - są w pewnym stopniu i pod pewnym względem uniezależnione od odbiorców ich prasy. Dlatego w swoich periodykach mogą poświęcać więcej miejsca problematyce społecznej - mniej interesującej potencjalnego czytelnika. Mając zapewnione odpowiednie środki finansowe na realizację czasopisma, nie muszą tym samym zabiegać o względy potencjalnych reklamodawców i ogłoszeniodawców. W wydawnictwach samorządów na czele znajdowała się oczywiście problematyka samorządowa, a dalej między innymi kultura i edukacja, sport, turystyka i rekreacja oraz gospodarka. W prasie samorządów terytorialnych zwracano większą uwagę na sprawy społeczno-gospodarcze. Następnie znajdowały się między innymi reklama, historia oraz sprawy „różne”.

Na podstawie wyników badań można zauważyć, iż zawartość prasy lokalnej ewoluuje w kierunku obejmowania przez nią w coraz większym stopniu zagadnień życia codziennego, w obrębie których dominują porady oraz materiały dziennikarskie o zróżnicowanym zakresie tematycznym - głównie jednak o zasięgu i charakterze lokalnym oraz reklama i ogłoszenia. 
Sfera społeczna jest wypierana przez zagadnienia życia prywatnego, rozrywkę i reklamę. W miejsce rozbudowanych - ilościowo i jakościowo - wiadomości i komentarzy z różnych dziedzin życia, nauki i techniki wstępują materiały reklamowe i promocyjne, ogłoszenia, informacje ze sportu oraz humor i rozrywka. Jest to nie tylko ilustracja określonych intencji dziennikarzy, zbierających i przygotowujących materiały prasowe do druku, lub też świadomej polityki redakcji (wydawcy) tych czasopism. Ale nade wszystko próba odwzorowania w publikacjach prasowych potrzeb i oczekiwań zgłaszanych przez czytelników.

W badaniach poświęconych prasie lokalnej zwraca się szczególnie uwagę na odejście od tematyki politycznej, ekonomicznej oraz produkcyjnej, które są wypierane przez problemy dotyczące zwykłych ludzi ${ }^{15}$. Podkreśla się jednocześnie, iż na ogólny obraz prasy lokalnej decydujący wpływ mają trzy rodzaje problematyki: społeczno-obyczajowa, kulturalna oraz sportowa, w których obrębie szczególnie mocno akcentowana jest tematyka historyczna ${ }^{16}$.

W prywatnej prasie komercyjnej zaczyna dominować problematyka przestępczo-aferowa oraz sportowo-rozrywkowa i reklamowo-ogłoszeniowa, czego świadectwem jest wzrastający udział tych grup tematycznych w ogólnej objętości omawianych wydawnictw.

Natomiast $w$ pismach samorządów terytorialnych rolę wiodącą odgrywają informacje dotyczące inicjatyw, roli i funkcji organów samorządowych, upodabniając tym samym te wydawnictwa do popularnych biuletynów informacyjnych.

\section{Summary}

The Author explains that the research into local press is mainly concerned with the departure from political, economic or manufacturing matters which are superseded by the problems of ordinary people. It is usually emphasized that the general outlook of local press is predominantly affected by three types of problems: social, cultural and sporting, with a particular stress on the historical aspect. The private commercial press is becoming dominated by issues concerning crime and scandals, sports and entertainment, and advertising and announcements as evidenced by an increasing proportion of

15 Por. M. Gierula, B. Grzonka, Prasa lokalna w latach 1989-1991, op. cit., s. 126.

16 Por. J. Adamska, Pisma samorzqdowe na Kielecczyźnie (1990-1992), w: Transformacja prasy polskiej 1989-1992, pod red. A. Słomkowskiej, Warszawa 1992, s. 218. 
these topics in the total volume of publications under consideration. However, in magazines which are produced by local governments the main topics concern the initiatives, importance and functions of local governments which makes these publications resemble popular notice bulletins. 